神経膠腫の質的診断の進歩

一画像と遺伝子一

木下 学1), 金村 米博 ${ }^{2}$, 成田 善孝 ${ }^{3)}$, 貴島 晴彦 4 )

1）旭川医科大学脳神経外科学講座，2）国立病院機構大阪医療センター臨床研究センター先進医療開発部，3）国立がん研究セ ンター中央病院脳脊髄腫瘍科, 4) 大阪大学大学院医学系研究科脳神経外科学

\title{
Advances in the Qualitative Diagnosis of Glioma: Correlation between Radiological Images and Genetic Alterations
}

\author{
Manabu Kinoshita, M.D., Ph.D. ${ }^{1)}$, Yonehiro Kanemura, M.D., Ph.D. ${ }^{2)}$, Yoshitaka Narita, M.D., Ph.D. ${ }^{3)}$, \\ and Haruhiko Kishima, M.D., Ph.D. ${ }^{4)}$
}

1) Department of Neurosurgery, Asahikawa Medical University, 2) Department of Biomedical Research and Innovation, Institute for Clinical Research, National Hospital Organization Osaka National Hospital, 3) Department of Neurosurgery and Neuro-Oncology, National Cancer Center Hospital, 4) Department of Neurosurgery, Osaka University Graduate School of Medicine

Radiological imaging plays a pivotal role in glioma patient care. It provides qualitative information about the tumor, such as the presumed pathological diagnosis and molecular status. In addition, it can provide anatomical information necessary for surgery and is helpful for monitoring treatment response. In this review, we discuss the following topics:

1. The progress in radiomics in the field of glioma.

2. Detailed analysis of the T2-FLAIR mismatch sign.

3. The potential of quantitative magnetic resonance (MR) imaging in the realm of qualitative glioma imaging.

Radiomics "focuses on improvements in image analysis, using an automated high-throughput extraction of large amounts (200+) of quantitative features of medical images". Despite extensive research, its diagnostic accuracy for detecting $I D H$ mutations is limited to approximately $85 \%$ sensitivity and specificity. The diagnosis of $1 \mathrm{p} / 19 \mathrm{q} \mathrm{co}^{-}$deletion is $10 \%$ less accurate than that of the $I D H$ mutation. The accuracy for diagnosing $M G M T$ promoter methylation is still uncertain.

Furthermore, the generalization of diagnostic algorithms derived from machine learning is another critical issue. While many researchers in the community have pushed radiomic research to the limit, a conventional qualitative imaging feature, namely,"the T2-FLAIR mismatch sign," was discovered. This imaging feature is able to identify IDH-mutant, $1 \mathrm{p} / 19 \mathrm{q}$ non-codeleted astrocytomas with a sensitivity of $20^{-}$ $50 \%$ and a specificity of almost $100 \%$. Through radiomic research of gliomas, the authors noticed potential effects of differences in image acquisition parameters between different institutions on the low sensitivity of the T2-FLAIR mismatch sign for detecting $I D H$-mutant and 1p/19q non-codeleted astrocytomas. Indeed, tuning the image acquisition parameters for FLAIR significantly improved the sensitivity of the T2-FLAIR mismatch sign. Finally, the future of MR-based glioma imaging relies on quantitative MR acquisition. This technique directly measures the tissue's T1- and T2-relaxation times, which provides valuable information for cancer tissue characterization. For example, we found that $I D H$-mutant, $1 \mathrm{p} / 19 \mathrm{q}$ non-codeleted astrocytomas contain tissues with very long T1- and T2-relaxation times (longer than 3,000 $\mathrm{ms}$ in T1-relaxation time). The commercialization of rapid quantitative MR acquisition technology could further boost the capability of radiomics.

(Received July 26, 2021 ; accepted September 1, 2021)

Key words : radiomics, quantitative MRI, $I D H$ mutation

Jpn J Neurosurg（Tokyo）31:4-10, 2022

連絡先：木下 学, 干 078-8510 旭川市緑が丘東 2 条 1 丁目 1-1 旭川医科大学脳神経外科学講座

Address reprint requests to: Manabu Kinoshita, M.D., Ph.D., Department of Neurosurgery, Asahikawa Medical University, 11-1, Midorigaoka-higashi 2, Asahikawa-shi, Hokkaido 078-8510, Japan 


\section{はじめに}

神経膠腫診療における放射線画像の役割は大きく腫瘍 の病理学的・分子遺伝学的診断, 手術計画, そして病変 の制御具合や再発検出の3つに分かれる。いわゆる lower grade glioma と総称されるようになった WHO グレード 2,3 神経膠腫は $I D H$ 遺伝子変異を伴うものか，そうで ないものかで大きく予後が異なり，そ机ゆ元手術加療を 含めて治療がめざすところと総合的な治療戦略がまった く異なってくる. IDH 変異型腫瘍は長期予後が見込まれ るため, 疾病を制御することを目的とする手術や放射線 化学療法と患者の就労を含めた生活の質 (quality of life : QOL）のバランスを熟慮する必要がある一方で, $I D H$ 野 生型腫瘍は予後がきわめて悪いことが予想され，早急な 積極的治療介入を必要とする。 IDH 遺伝子変異をはじめ とする神経膠腫の分子遺伝学的性質の事前診断は神経膠 腫患者の治療戦略を立てるうえで有用な情報となるた め, 臨床現場ではかつてよりこのような技術の開発が期 待されていた。たとえば 2000 年台前半に $1 \mathrm{p} / 19 \mathrm{q}$ 共欠失 の有無という神経膠腫の分子遺伝学的特徵が患者の予後 と相関することが知られたが4)，その当時から MRIで $1 \mathrm{p} / 19 \mathrm{q}$ 共欠失の有無を推定しようとする試みが発表さ れている ${ }^{12)}$. 放射線画像で神経膠腫の分子診断を行おう とする研究は年々盛んになり，2020 年には年間 400 報ほ どの学術論文が発表されている。本稿では直近 10 年で この分野においてどのような研究成果があったのかを(1) 神経膠腫の radiomics 研究, (2)T2-FLAIR mismatch sign の 発見, そして(3)定量的 MRIへの期待という 3 項目に分け て説明する。

\section{神経膠腫の radiomics 研究}

Radiomics は 2012 年に Lambin ${ }^{10)}$ が総説論文の中で 提唱した学術用語である。彼らは “Radiomics focuses on improvements of image analysis, using an automated highthroughput extraction of large amounts $(200+)$ of quantitative features of medical images” と記載しており, 画像解析の 「自動化」, 画像特徴の「網羅的」そして「定量的」解析 が radiomics という解析方法の根幹であると明言してい る。直感的には定量的なデータの集合と思われる放射線 画像であるが，その解析や解釈には観察者の定性的な評 価が主たる役割を果たすことが多い.そのような再現性 や個々の観察者の評価というバイアスを可能なかぎり回 避することが radiomics の大きな目的の 1 つである. Radiomics 研究では複数の医療機関や医療機器から得ら
れた画像を一律に解析するため, 画像の均一化という作 業が必須となり，このプロセスを経てょうやく定性的な 医用画像を定量的に解析できるようになる (Fig. 1) ${ }^{14)}$. 定量的解析には腫瘍を中心とする関心領域内の平均値, 標準偏差, エントロピーなどのヒストグラム解析や画像 パターンの繰り返し出現が測定できるグレーレベルの同 時生起行列解析 (gray-level co-occurrence matrix: GLCM）などが含まれる。このような画像解析手法は生 データである画像にかなりの人為的操作を加えることを 必要とし，このような作業工程が最終的な診断精度に影 響を及ぼしている可能性がある。筆者らの研究経験でも さまざまな画像解析アルゴリズムの改良を試みても，神 経膠腫の IDH 遺伝子変異予測精度はお打よそ85\%を境 に頭打ちになる ${ }^{3)}$. 最近発表されたメタアナリシス報告 によれば，神経膠腫の $I D H$ 遺伝子変異の感度は $85 \%$ ・ 特異度は $83 \%$ であった。 $1 \mathrm{p} / 19 \mathrm{q}$ 共欠失のそれぞれは $70 \%$ と $72 \%$ であり, 放射線画像による事前予測の難易度 は上がり, MGMT プロモーター領域のメチル化の有無 は報告論文数そのものが大幅に減少している状況であっ た6)。また，あるコホートで高い診断精度を誇る診断ア ルゴリズムが開発できても，別のコホートで検証した場 合には開発されたアルゴリズムの予測診断精度が大幅に 低下寸る現象も指摘されており，開発された技術の沉用 化をどのようにして実現するのか知恵を試されている ${ }^{21}$.

\section{定性的画像評価再考 -T2-FLAIR mismatch sign の発見—}

神経膠腫画像に対する radiomics が熱心に追求されて いる裏で, 定性的な画像評価を再考する研究が発表され た ${ }^{14)}$ 。これは, 米国のがん画像公開データベースである The Cancer Imaging Archive（TCIA）の低悪性度神経膠腫 データセットをすべて読影し直し, IDH 遺伝子変異と相 関する画像特徵の同定を試みたものであった. その研究 の中で, T2-FLAIR mismatch sign が感度は低いものの $I D H$ 変異型星細胞腫のきわめて特異的な画像所見である ことが見出された. T2-FLAIR mismatch sign は T2 強調 画像では腫瘍全体が高輝度に描出される一方で FLAIR 画像では腫瘍本体が逆に低輝度に描出され, 腫瘍周囲に だけ高輝度信号所見が残存する現象を指す（Fig. 2)。最 初の報告では T2-FLAIR mismatch sign は IDH 遺伝子変 異星細胞腫に対して感度は 22〜 46\%であるものの, 特異 度は $100 \%$ に達することが示された。また観察者間での 相関性に関する指標である $\kappa$ 值も $0.728 \sim 0.747$ を推移 し, 定性的評価であるものの, 実臨床の視点からはきわ 


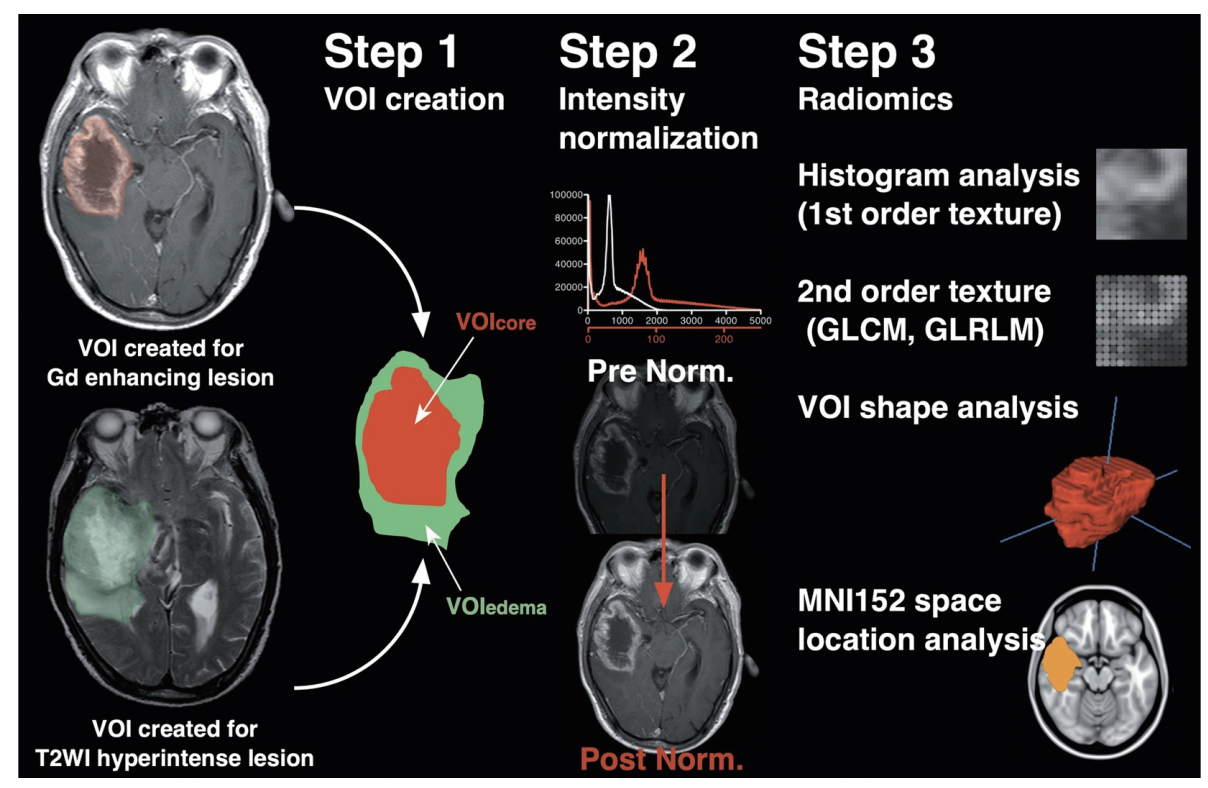

Fig. 1 Illustration of the workflow for image analysis

First, the operators create regions of interest for feature extraction. Subsequently, intensity normalization of all images is performed, and first-order and second-order texture analysis, volume of interest shape analysis, and location analysis are performed. Cited from reference 14 under a Creative Commons Attribution 4.0 International License.

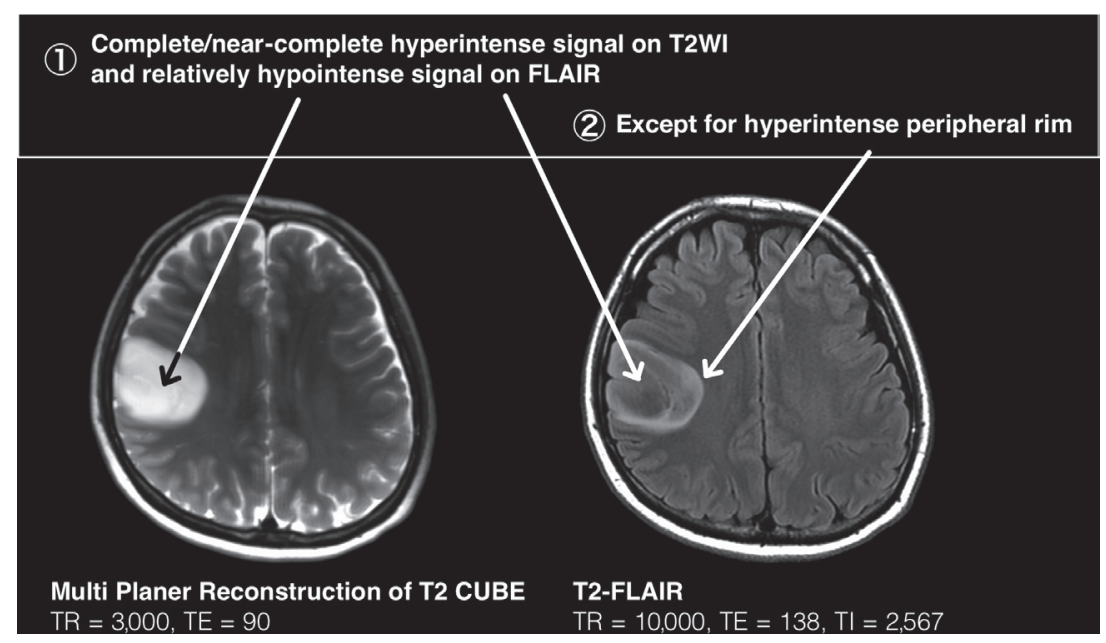

Fig. 2 A Representative case of T2-FLAIR mismatch in astrocytoma, $I D H$-mutant

Definition of a T2-FLAIR mismatch. A 37-year-old woman harbored an $I D H$-mutant astrocytoma in the right parietal lobe. The hyperintense lesion on the T2-weighted image is reversely hypointense on FLAIR, leaving a hyperintense rim around the lesion.

めて有望な画像所見であろうと結論された。この研究結 果は欧州のデータセットでも再現され，IDH 遺伝子変異 星細胞腫に対して感度が $50 \%$, 特異度が $100 \%$ でるこ とが報告された ${ }^{1)}$ 。その一方で定性的な画像所見である
ため，観察者がT2-FLAIR mismatch sign の定義をときと してやや拡大解釈気味に応用すると診断精度が大きく変 化する問題も指摘されている. Juratli $ら^{7)}$ は T2-FLAIR mismatch sign が IDH 遺伝子変異星細胞腫の $73 \%$ に出現 


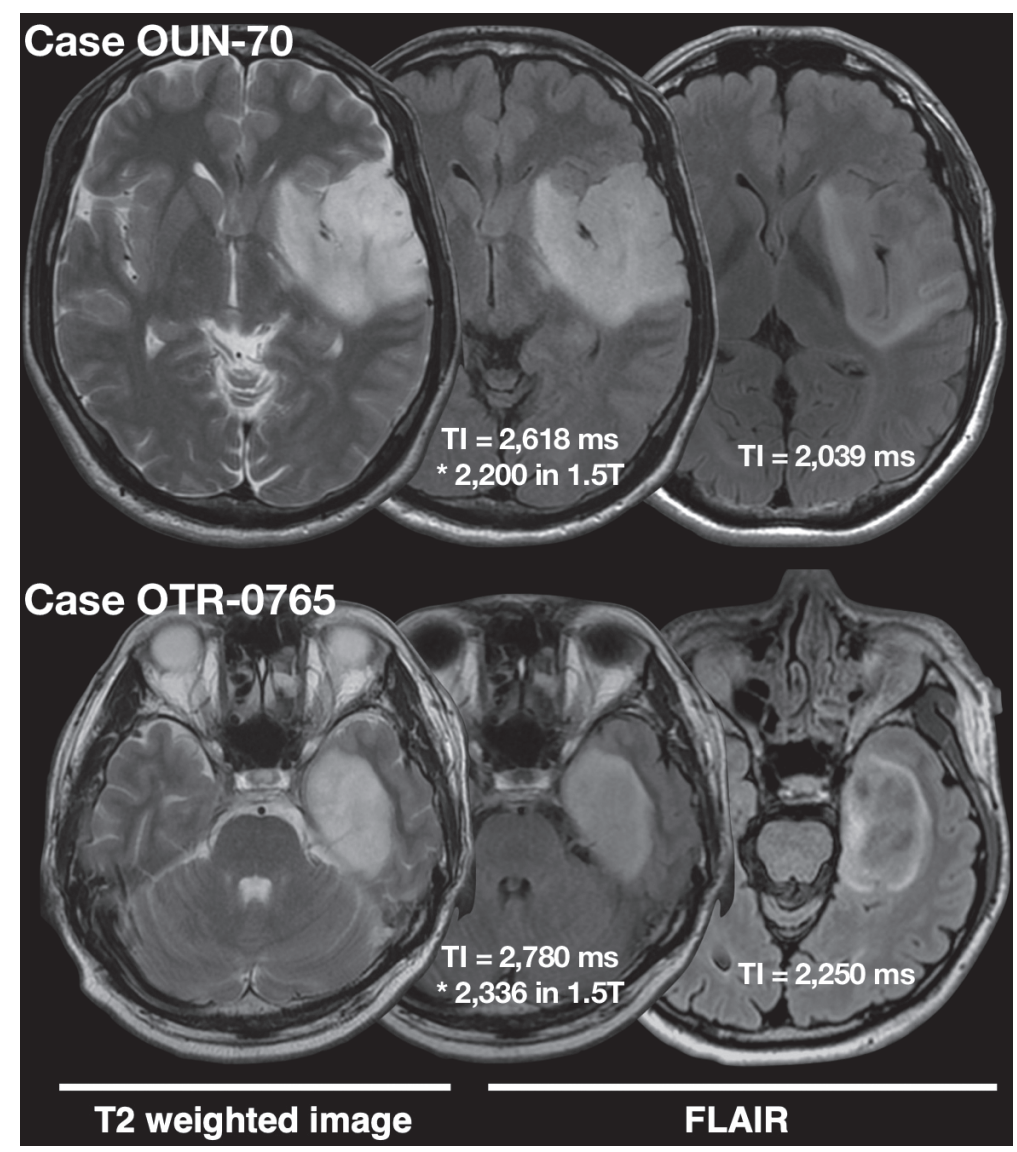

Fig. 3 Impact of inversion time for FLAIR acquisition on the T2-FLAIR mismatch sign

This figure shows two representative $I D H^{-}$mutant and nonCODEL astrocytomas obtained as two FLAIR images scanned with different inversion times. Both cases highlight the importance of inversion time (TI) for FLAIR acquisition for visualization of the T2FLAIR mismatch sign.

Cited from reference 9 under a Creative Commons Attribution 4.0 International license.

すると報告したが，初回報告の論文著者の 1 人である Jain 氏と Juratli 氏との個人的な議論の中で，T2-FLAIR mismatch sign の陽性基準解釈が異なっていたことが記 録されていることは興味深い5)。著者らはこれまでの radiomics 研究で得られた解析結果から $I D H$ 遺伝子変異 星細胞腫における T2-FLAIR mismatch sign の陽性率が 低いことの理由の 1 つに撮影そのものの施設間での差異 が関係しているのではないかと仮説を立てた。この仮説 は radiomics 研究を進兴えで必要な画像の均一化作 業の中で T2 強調画像と FLAIR 画像の施設間の差異が大 きいことが確認されていたことに基づいたものである. 特に FLAIR 画像は反転時間 (inversion time) というパラ メータによって大きく画像の特性が変化し, 施設によっ てこの值の設定は異なる。 FLAIR画像は脳卒中診療で脳
浮腫領域を明瞭化するために脳内から髄液信号を消去す ることを目的として開発されたため，多くの施設では髄 液信号消去を狙って反転時間を 2,700 ミリ秒前後に設定 していることが多い，その一方で神経膠腫を狙って静磁 場 3 テスラのもとで反転時間を 2,400 ミリ秒以下（静磁 場 1.5 テスラのもとでは 2,016 ミリ秒以下）に FLAIR 画 像の撮影条件を調整すると, 通常の FLAIR 画像では視認 できなかった T2-FLAIR mismatch sign が容易に確認で きることがあり（Fig. 3)，ここに挙げるような画像解析 研究において, 脳腫瘍の画像撮影条件そのものがきわめ て重要な要素であることがうかがい知れる。T2-FLAIR mismatch sign を最初に報告した研究の生デー夕を再解 析すると，FLAIR 画像が神経膠腫の画像化に適した撮影 条件で撮られている症例とそうでない症例でIDH 遺伝 


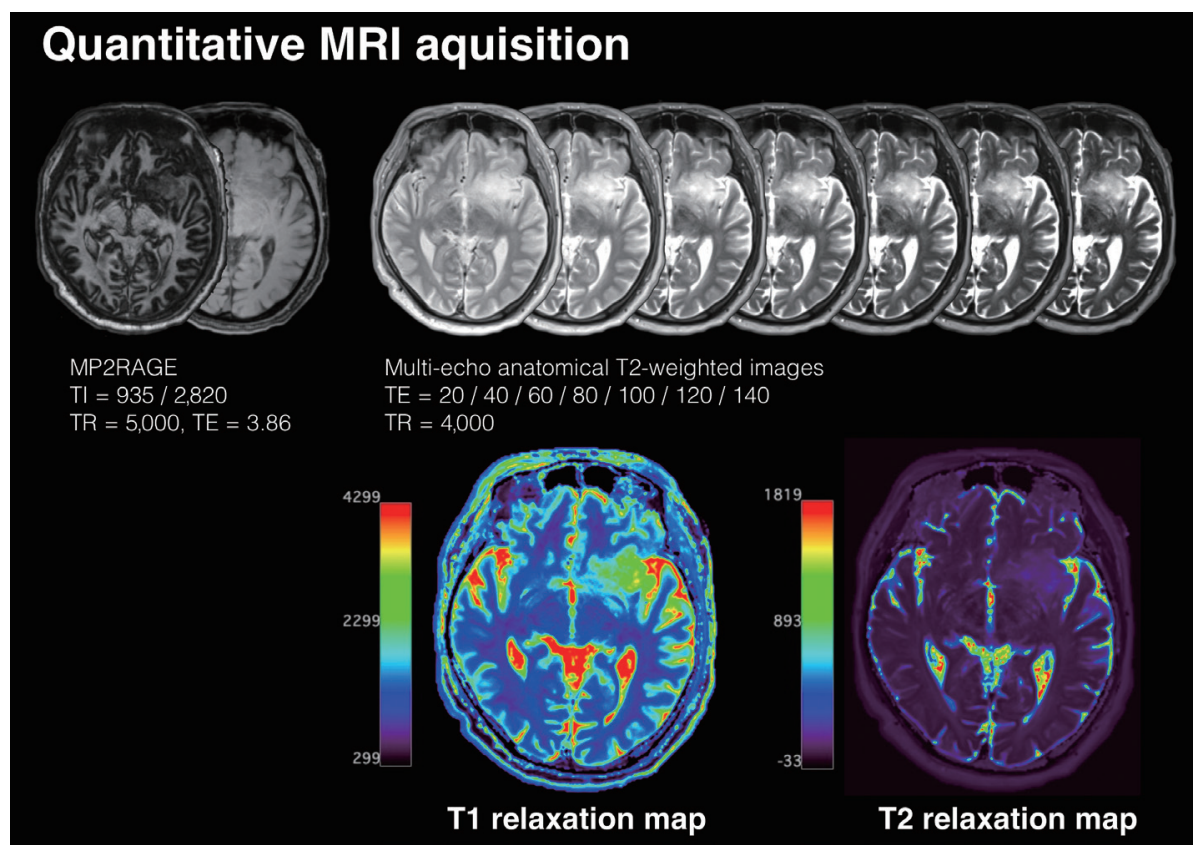

Fig. 4 Representative case of quantitative magnetic resonance imaging of a glioma

Imaging was performed using a 3T MR scanner (Prisma ; Siemens Healthcare, Erlangen, Germany). T1-relaxometry was achieved by first acquiring MP2RAGE images and then converting those images into T1-relaxation time maps. At the same time, T2-relaxometry was achieved by first acquiring multi-echo T2weighted images which were subsequently converted into T2-relaxation time maps, with both relaxometries performed via Bayesian inference modeling.

子変異星細胞腫における T2-FLAIR mismatch sign の診 断精度は異なることが明らかとなっている ${ }^{8)}$.

\section{次世代 MRI 撮影技術一定量的 MRI 撮影一}

MRI の基本原理は静磁場内で対象組織に対してラジ オ波を照射し組織の水素原子の原子核スピンの回転軸を 人為的に変化させた後の回転軸の回復過程を測定するこ とに依存している，回転軸の回復には縦方向の回復と横 方向の回復があり，それぞれを $\mathrm{T} 1$ 緩和と $\mathrm{T} 2$ 緩和と呼 ぶ。さまざまな組織の特徵に依存して $\mathrm{T} 1$ 緩和と $\mathrm{T} 2$ 緩和 の回復速度（T1 緩和時間と $\mathrm{T} 2$ 緩和時間）は異なり, T1 強調画像や $\mathrm{T} 2$ 強調画像は組織間の $\mathrm{T} 1$ 緩和時間や $\mathrm{T} 2$ 緩 和時間の差異を強調し，これを画像のコントラストとし て用いている。換言すると $\mathrm{T} 1$ 強調画像や $\mathrm{T} 2$ 強調画像は 組織の $\mathrm{T} 1$ 緩和時間や $\mathrm{T} 2$ 緩和時間そのものを測定してい ない.この画像の定性性がつまるところ radiomics 研究 にしても，T2-FLAIR mismatch sign の解釈にしても究極 的な問題となる.この定性的問題を解決するために MRI の定量的な撮影技術の開発が精力的に進められてきた。 筆者らもこれまでに神経膠腫の $\mathrm{T} 1$ 緩和時間画像と $\mathrm{T} 2$ 緩
和時間画像を作像してきたが (Fig. 4)，得られた画像は 最初から定量的デー夕となっているため組織性状の直接 的な比較検討が可能である. 定量的 MRI の解析から T1 緩和時間を例にとると 3,000 ミリ秒以上の組織は $I D H$ 遺 伝子変異星細胞腫である可能性がきわめて高いことが明 らかとなった ${ }^{9}$. 定量的 MRI は QRAPMASTER (quantification of relaxation times and proton density by multi-echo acquisition of a saturation-recovery using turbo spin-echo readout）という撮影シーケンスを用いて，複数の $\mathrm{T} 1$ 強 調系画像と T2 強調系画像を取得し T1 緩和時間画像と $\mathrm{T} 2$ 緩和時間画像を再構成する方法と, T1 緩和時間と $\mathrm{T} 2$ 緩和時間が既知であるさまざまな組織にラジオ波を照射 した際の信号に関する膨大な辞書を作成しておき，それ に対して実際の撮影時の信号を参照して高速撮影する MRF（MR fingerprinting）に大別される ${ }^{13)}$.いずれの手 法をとっても高速に定量 MRI が撮影できる基礎的な技 術開発が進んでおり, この分野の大きな飛躍が期待され $ろ^{11)}$. 


\section{おわりに}

MRI は神経膠腫診療の中心的な役割を果たす医療技 術であるが，そこに関わる技術開発も多岐にわたり，新 規技術の利点と問題点を十分に理解しながら臨床応用や 技術開発に取り組んでいく必要があろう。

\section{COI}

著者全員は日本脳神経外科学会への COI 自己申告の登録を 完了しています。本論文に関して開示すべき COI はありませ h.

\section{文 献}

1) Broen MPG, Smits M, Wijnenga MMJ, Dubbink HJ, Anten MHME, Schijns OEMG, Beckervordersandforth J, Postma AA, van den Bent MJ : The T2-FLAIR mismatch sign as an imaging marker for non-enhancing IDH-mutant, $1 \mathrm{p} / 19 \mathrm{q}^{-}$ intact lower-grade glioma : a validation study. Neuro Oncol 20: 1393-1399, 2018.

2) Choi YS, Bae S, Chang JH, Kang SG, Kim SH, Kim J, Rim TH, Choi SH, Jain R, Lee SK : Fully automated hybrid approach to predict the IDH mutation status of gliomas via deep learning and radiomics. Neuro Oncol 23:304-313, 2021.

3) Fukuma R, Yanagisawa T, Kinoshita M, Shinozaki T, Arita H, Kawaguchi A, Takahashi M, Narita Y, Terakawa Y, Tsuyuguchi N, Okita Y, Nonaka M, Moriuchi S, Takagaki M, Fujimoto Y, Fukai J, Izumoto S, Ishibashi K, Nakajima Y, Shofuda T, Kanematsu D, Yoshioka E, Kodama Y, Mano M, Mori K, Ichimura K, Kanemura Y, Kishima H : Prediction of IDH and TERT promoter mutations in low-grade glioma from magnetic resonance images using a convolutional neural network. Sci Rep 9: 20311, 2019.

4) Ino Y, Betensky RA, Zlatescu MC, Sasaki H, Macdonald DR, Stemmer-Rachamimov AO, Ramsay DA, Cairncross JG, Louis DN : Molecular subtypes of anaplastic oligodendroglioma : implications for patient management at diagnosis. Clin Cancer Res 7: 839-845, 2001.

5) Jain R, Johnson DR, Patel SH, Castillo M, Smits M, van den Bent MJ, Chi AS, Cahill DP: "Real world" use of a highly reliable imaging sign : "T2-FLAIR mismatch" for identification of IDH mutant astrocytomas. Neuro Oncol 22: 936$943,2020$.

6) Jian A, Jang K, Manuguerra M, Liu S, Magnussen J, Di Ieva
A : Machine learning for the prediction of molecular markers in glioma on magnetic resonance imaging: a systematic review and meta-a nalysis. Neurosurgery $89: 31-44,2021$.

7) Juratli TA, Tummala SS, Riedl A, Daubner D, Hennig S, Penson T, Zolal A, Thiede C, Schackert G, Krex D, Miller JJ, Cahill DP : Radiographic assessment of contrast enhancement and T2/FLAIR mismatch sign in lower grade gliomas : correlation with molecular groups. J Neurooncol 141: 327-335, 2019.

8) Kinoshita M, Arita H, Takahashi M, Uda T, Fukai J, Ishibashi K, Kijima N, Hirayama R, Sakai M, Arisawa A, Takahashi H, Nakanishi K, Kagawa N, Ichimura K, Kanemura Y, Narita Y, Kishima $\mathrm{H}$ : Impact of inversion time for FLAIR acquisition on the T2-FLAIR mismatch detectability for IDH-mutant, non-CODEL astrocytomas. Front Oncol 10:596448, 2021.

9) Kinoshita M, Uchikoshi M, Sakai M, Kanemura Y, Kishima $\mathrm{H}$, Nakanishi $\mathrm{K}$ : T2-FLAIR mismatch sign is caused by long $\mathrm{T} 1$ and T2 of IDH-mutant, 1p19q non-codeleted astrocytoma. Magn Reson Med Sci $20: 119-123,2021$.

10) Lambin P, Rios-Velazquez E, Leijenaar R, Carvalho S, Stiphout RGPM van, Granton P, Zegers CML, Gillies R, Boellard R, Dekker A, Aerts HJWL : Radiomics : extracting more information from medical images using advanced feature analysis. Eur J Cancer 48: 441-446, 2012.

11) Ma D, Gulani V, Seiberlich N, Liu K, Sunshine JL, Duerk JL, Griswold MA : Magnetic resonance fingerprinting. Nature $495: 187-192,2013$.

12) Megyesi JF, Kachur E, Lee DH, Zlatescu MC, Betensky RA, Forsyth PA, Okada Y, Sasaki H, Mizoguchi M, Louis DN, Cairncross JG : Imaging correlates of molecular signatures in oligodendrogliomas. Clin Cancer Res 10:4303-4306, 2004.

13）中澤美咲, 糀沢宏之, 青木茂樹: Synthetic MRI と MR fingerprinting. INNERVISION $\mathbf{3 0}: 16-18,2015$.

14) Patel SH, Poisson LM, Brat DJ, Zhou Y, Cooper L, Snuderl M, Thomas C, Franceschi AM, Griffith B, Flanders AE, Golfinos JG, Chi AS, Jain R: T2-FLAIR mismatch, an imaging biomarker for IDH and $1 \mathrm{p} / 19 \mathrm{q}$ status in lower-grade gliomas: a TCGA/TCIA project. Clin Cancer Res 23 : 6078-6085, 2017.

15) Sasaki T, Kinoshita M, Fujita K, Fukai J, Hayashi N, Uematsu Y, Okita Y, Nonaka M, Moriuchi S, Uda T, Tsuyuguchi N, Arita H, Mori K, Ishibashi K, Takano K, Nishida N, Shofuda T, Yoshioka E, Kanematsu D, Kodama Y, Mano M, Nakao N, Kanemura Y : Radiomics and MGMT promoter methylation for prognostication of newly diagnosed glioblastoma. Sci Rep 9: 14435, 2019. 
旨

神経膠腫の質的診断の進歩

一画像亡遺伝子一

木下 学 金村 米博 成田 善孝 貴島 晴彦

神経膠腫診療における放射線画像の役割は大きく, 放射線画像で神経膠腫の分子診断を行おうとす る研究は年々盛んになっている. 本稿では直近 10 年でこの分野においてどのような研究成果があっ たのかを(1)神経膠腫の radiomics 研究, (2)T2-FLAIR mismatch sign の発見, そして(3)定量的 MRIへ の期待という 3 項目に分けて説明し, 神経膠腫の放射線画像による質的診断がどのように発展してき たか, あるいは現状ではどのような問題点が指摘できるのかについて理解することをめざす.

脳外誌 $31 ： 4-10,2022$ 